\author{
MAGDALENA JUREWICZ \\ Uniwersytet im. Adama Mickiewicza w Poznaniu \\ magdalen@amu.edu.pl
}

\title{
Symbol in translation
}

\begin{abstract}
The subject for reflection in this paper is the translational challenge posed by the rendering of linguistic representations of national stereotypes, based on the example of the flower Edelweiss from the song Edelweiss which became a word-symbol for the inhabitants of the U.S.A. The translation of this stereotype created in the U.S.A., where the symbol of Edelweiss gained an added meaning, means that the translator of the English-German language pair is forced to explain the exo-cultural associations to those receivers who are enculturated in the country of this symbol's origin.
\end{abstract}

KEYWORDS: national stereotype; cultural associations; overtranslation.

\section{INTRODUCTION}

This paper deals with the translational challenge posed by the translation of symbols, especially symbols which are used as language representations of national stereotypes. The paper also focuses on aspects of the didactics of translation which result from the analysis of the above mentioned case. In this context, the German noun "Edelweiss", which describes an Alpine plant, is examined. For Americans, the Alpine plant edelweiss has become a symbol of Austrian resistance against Nazi persecution. It is also the main subject of a song from the musical, The Sound of Music, by Richard Rodgers (music) and Oscar Hammerstein II, which premiered on Broadway in 1959. Parallelly, a discrepancy between the associations with a given symbol, as dependent on the nationality and the place of residence of students will be presented. It is based on a short pilot study of a non-representative group of students of translation in Poznań and Vienna who were asked one question: What do you associate edelweiss with? This type of questionnaire, researching associations with a word perceived as a symbol, helps to include its actual meaning, incorporated e.g. in the students' responses. It can enrich 
the didactics of translation by surveying students from the country where the word and symbol originated and where it is to appear after the translation.

In the modern world, because of the media's influence, especially television and the Internet, we can observe the transgression of many elements from various cultures. Therefore, the translator faces the challenge of implementing elements of one culture into the structure of another. Frequently, this is done by incorporating whole phrases into a new language. However, this is often done without incorporating the associations which the symbol carries. This is especially the case with words - symbols whose translation requires a more or less limited transfer of meaning.

First, let us specify which aspects of the understanding of the notion of symbol are essential for translation studies. In Greek, a symbol originally referred to a token made of clay (tessera hospitalis).

A host entertaining a guest gives to the guest the so called tessera hospitalis, i.e. he breaks the token into two, he keeps a half and the other half is handed to the guest, so that after thirty or fifty years' time, when the guest's descendant arrives in the host's house they can recognize each other by putting the halves together. An ancient passport: this is the first technical meaning of a symbol." (Walczak 2011: 88)

The difference between the symbol and the sign is in the additional nontransparent meaning of the symbol, because the full meaning of the symbol indicates its indirect/second meaning. This second meaning is, however, culturally conditioned. Symbols appear and disappear in the given society that produces them. Thus, they depend on human consciousness, not so much on an individual but on a certain community, and as a result they are not meaningful to everyone. Individuals are not capable of creating symbols on their own and in the way they like, though symbols originate in their minds. A symbol becomes so when it has been accepted by a community (see Tillich 1994: 148; Jung 1976 after Walczak 2011: 90). Symbols are often positioned in a given culture and, additionally, in a given time. With the passage of time their meaning may be altered or lost.

On the other hand "the symbol uncovers what is idiosyncratic (i.e. characteristic for an individual or a community) and determined by historical or cultural conditions as well what is universal and transcends historical or cultural influence" (Walczak 2011: 90).

Symbols, then, cannot be created loosely but only interpreted in this way. Their meaning is decoded either intuitively or through reflection (Walczak 2011: 93). The point is to get to the hidden sense of the symbol, which seems to be the translator's essential role. 
The translational challenge we are talking about here means that the translation of the symbol, in this case the translation of the stereotype created in the USA where Edelweiss acquires a new, additional meaning, forces ${ }^{1}$ the translator dealing with an English-German language pair to explain its new (exo-cultural) associations to an audience who were enculturated in the country where the symbol originated.

The symbol discussed here is the carrier of a stereotypical image of a nation created by the Other. Through this symbol a fragment of reality of one country, namely Austria, was created in another, the USA. The image of Austrians as shown in the musical had a very strong impact on the creation of a stereotypical view of a fragment of Austrian history in the USA.

\section{EDELWEISS AND ITS PATRIOTIC SYMBOLISM}

Edelweiss (Leontopodium alpinum http://www.e-katalogroslin.pl/plants/ 3687,szarotka-alpejska_leontopodium-alpinum, Date of access 4.11.2016), which we are going to discuss here, is an Alpine plant with white petals and yellow centres. It grows in the Tatra Mountains and is protected as an endangered species.

In Germany, and even more so in Austria and Switzerland, where the mountains occupy a special place in the inhabitants' consciousness, the Edelweiss has had many symbolic meanings. For example, in Austria it is depicted on a two-cent coin. In Switzerland, it is regarded as a symbol of chastity and innocence and is also a Swiss national flower. (Those who are interested in the symbolism of the edelweiss can find more on this subject in German works (see Scheidegger 2008; Diem 1995: 402-403 or <http:/ / www.museumderuner hoertendinge.de/dinge_2003/edelweiss/edelweiss.htm> (4.11.2016), where one can read about the origins of the legend of the edelweiss).

The symbolism of chastity and innocence associated with the flower probably stems from its name, which literary means 'noble whiteness'. However, there is a second aspect of the symbolism of the flower connected with patriotism, which has a bearing on the musical The Sound of Music.

In 1907, by order of His Royal Highness the Emperor Franz Joseph I, this flower was chosen as an insignia for Austro-Hungarian Alpine troops (mountain riflemen), and later the flower served as an insignia for German Alpine troops, also².

1 See Bednarczyk (2005: 44) and her translation model. The example discussed here seems to generate different associations for an average recipient of the translated text from those associations which the sender of the original had.

${ }^{2}$ Cf. <https://de.wikipedia.org/wiki/1._Gebirgs-Division_(Wehrmacht)> (Date of access 4.11.2016) We can see there the badge of $1^{\text {st }}$ Mountain Division of the Wehrmacht from the 
The lyrics of these military formations' patriotic songs often relied on the symbolism of chastity and innocence of this modest flower. They did not, however, describe the human actions of the troops. An example is Marsch der Gebirgsjäger, which was written by Karl Heinz Räntzsch in around 1940 for the formation which later became infamous for their bloody killings in Greece, the inhuman massacre of Italian soldiers on the island of Kefalonia ${ }^{3}$ :

Es steht ein kleines, kleines Edelweiß auf einer steilen, steilen Felsenhöh. Umgeben ist's von Schnee, ja Schnee und Eis, das kleine Edel-, Edelweiß.

Refrain:

Ich grüße dich, mein Schatz, vergiß mich nicht, mein Schatz, von einer steilen, steilen Felsenhöh, ja Höh. Wo rauh der Bergwind weht, ein kleines Blümlein steht, das kleine Edel-, Edel-, Edelweiß.
2. Wir stehen auch auf dieser Felsenhöh im Kampf mit Wetter, Eis, ja Eis und Schnee. Wir halten Wacht fürs deutsche Vaterland und schützen's vor des Feindes Hand.

Refrain:

3. Und sollte ich nicht kehren mehr zurück, so weine nicht, ja weine nicht mein Schatz. Ein steiler Felsen ist mein stilles Grab, das man zu letzten Ruh mir gab. Refrain:

Source: Scheidegger 2008: 44 (see also: Meyer 2008).

After the Second World War, the songs lost their popularity in Germany and Austria, although as Scheidegger (2008: 45) notes, there were attempts within the circles of the members of this formation to hide their war atrocities by means of the music of brass instruments and references to the symbolism of the edelweiss (its chaste purity).

\section{THE SOUND OF MUSIC AND THE EDELWEISS SONG}

Meanwhile, and somewhat ironically, the use of the symbol of the edelweiss as a symbol of Austrian resistance was growing in popularity. In 1959, a musical by Richard Rodgers (music) and Oscar Hammerstein II, The Sound of Music, entered Broadway. The musical tells the story of Captain von Trap who, in the $88^{\text {th }}$ minute of the musical, sings a song about an Alpine plant

Second World War. This division was even nicknamed the Edelweiß-Division, and was regarded by Adolf Hitler as "his Guard Division".

${ }^{3}$ This event is portrayed in the film Captain Corelli's Mandolin, an American-British-French melodrama from 2001 based on the novel by Louis de Bernières, directed by John Madden, starring Nicolas Cage and Penelope Cruz. 
Edelweiss ${ }^{4}$. The name of the song is not translated into English, however, and is used in its original German form. (online see <http:/ / www.youtube.com/

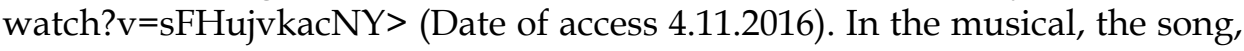
which is sung by the whole family in one of the last scenes, may be understood as a call to rise up against the Nazis (see Drügh 2009: 87-206; Strasser 2000: 291), and is remembered by Americans thanks to a popular movie of the same title directed by Robert Wise and released in 1965, which starred Julia Andrews and Christopher Plummer. The film (which is referred to in other films such as Lars von Trier's Dancer in the Dark (2000) or the recent popular comedy The Pacifier by Adam Shankman (2005)) created a very convincing although not very truthful picture of Austria as an idyllic country where the majority resisted Hitler. What we are observing here is the typical creation of a stereotype - a symbol about a country where the symbol originated from the people of another country. However, the symbol also exists in Austria, which complicates the translator's task.

\section{TRANSLATION OF THE EDELWEISS SYMBOL}

Let us begin with an anecdote about Edelweiss. President Ronald Reagan, during his talks with the Austrian President, quoted some lines from the song Edelweiss (which allows us to conclude that Reagan knew The Sound of Music as many Americans did), but the President of Austria had no idea what country President Reagan was referring to since The sound of Music is not well-known in Austria (Strasser 2000: 291).

The translational task that appears in the situation described above illustrates the complex nature of translation when we are dealing with a word which sounds the same in two languages but has a different load of associations and is translated back into the language it originally comes from. Here is a word (Edelweiss) "a" in language A (in our case German) which means "a" (an Alpine plant) and has a number of associations a1, a2, a3... a n. The same word also exists in language B (in our case English). It sounds the same (Edelweiss) "a", and it means the same "a" (an Alpine plant), but evokes association $\mathrm{b}$ (with the film The Sound of Music). Translation from language B

${ }^{4}$ It should not to be confused with another song, very popular in the 90tees: "Bring Me Edelweiss" from an Austrian electronica/dance band Edelweiss, consisting of remixers Martin Gletschermayer, Matthias Schweger and Walter Werzowa. Edelweiss reached the number one position with their hit "Bring Me Edelweiss". The single was a hit in many European countries. Borrowing large parts of its melody from ABBA's "SOS" and Indeep's "Last Night a DJ Saved My Life", the song humorously targeted Austrian ski resorts and yodeling and sold five million copies worldwide. 
to language A cannot be based on preserving just "a", because despite the fact that the word has the same meaning in the two languages, the change in associations with this word in languages A and B can lead to misunderstanding. In translation, it is necessary to provide the associations in a footnote but they should be limited only to those which are essential in a given context.

The matter becomes more complicated when we are dealing with interpreting. It seems that during consecutive translations on official visits it is necessary to provide some additional explanations, in this case an explanation of a stereotype of Austria in the USA when translating from English into German, since without this additional explanation a misunderstanding might occur. However, it is the translator who decides whether this explanation is necessary or not (it is difficult to imagine additional explanations being given during an official address broadcast by the media, but they will necessarily be given in free talks during gala dinners or behind the scenes as the anecdote quoted at the beginning shows).

In the case of audio-visual translation, the translator, by leaving Edelweiss in the target text, can evoke associations with chastity. At the same time, the image itself may evoke negative connotations in a German viewer who might refer the image to associations a1, a2..., a n so common in the German language (for example associations with the Gebirgsjägerbrigade).

At this point I would like to refer to the anonymous questionnaire done in Austria which was mentioned in the introduction. This research, which included a questionnaire with one question in German (Womit assoziieren Sie das Wort Edelweiß?), was conducted in 2016 among a group of students from the University of Vienna. Among the respondents the majority were Polish students (33) and students who declared Austrian origin (7) as well as individual students of different origin (two Russians, one Hungarian, one Italian and people with multiple citizenship: one person declaring Polish, German and Austrian origin as well as one person declaring Italian and Polish origin born in Austria) ${ }^{5}$. They were students at the advanced level of German who studied at the masters level or in the last year of bachelor's degree. The responses were as follows: Polish students associated edelweiss mainly with the Alps (7 responses), beer brand with this name (5), the white colour (4) and a flower $(4)^{6}$. Austrian students associated Edelweiß with Beer

\footnotetext{
${ }^{5}$ Research conducted during the following classes taught by the author: Translatorische Basiskompetenz, Basis Translation, Übersetzen Gesisteswissenschaften as well as Dialogdolmetschen taught by Mrs Joanna Ziemska whom I would like to thank cordially once more.

${ }^{6}$ Other individual answers given by Poles in Austria were: Sisi, the Austrian flag, teeth, ivory, snow, restaurant, wine, flower, aristocracy, purity, royal house, love and even a wedding dress.
} 
(7), mountains (4), a flower (3) and also with films about the motherland (1), meadows (1), the Alps (1) and Austria (1). One of the Russian students associated the term with a flower and vodka, the other only with a flower. The Hungarian student associated it with a flower. The person with Polish, German and Austrian citizenship had many associations: the Alps, mountain pasture, rarity, Bavaria, Austria, snow, winter holidays and wandering. The person of Italian and Polish origin born in Austria indicated a mountain flower and beer.

As can be seen, contemporary meanings of the symbol of edelweiss given by the students correspond only partially (a mountain flower, the Alps, films about the motherland) with the meanings of this symbol given above.

The questionnaire described above helps the lecturer who teaches in the country of the target culture to broaden given semantic fields of a given symbol with the most contemporary associations. This can be useful e.g. in the translation of adverts of a given product for defined target groups.

Last but not least, what should the translator do when s/he is translating "a" into language $C$ (for example from English into Polish) if the associations with the word c (c1, c2) are very few, and if the understanding of the word by speakers of language $C$ does not guarantee the correct reading of the symbol. In Poland, edelweiss is well-known, but there are not many associations with the word. It is only a white flower. This is all that an average Pole knows about it, provided they have any associations with the flower at all. To prove the case in point, let us use as an example from the findings of a short anonymous survey conducted among a non-representative group of second year students of Applied Linguistics. The question asked in the survey was: what do you associate edelweiss with? 12 out of 19 students said they associate edelweiss with a white flower, with a grey object, a bird, a dish (an apple pie), an animal or a holiday resort named after the flower. Only one student said the flower grows in the mountains. The survey was conducted in 2013 among students of applied linguistics (year three). An identical survey was repeated in 2016 among 36 students of BA studies (year one and two). The answers were as follows: edelweiss is associated with a plant (17, out of which two people said that it is a mountain plant under protection and one that it is a type of carrot), secondly - with an animal (5, out of which two people associated it with a name for a kitten) and with a dish (7 - apple pie). Some students did not associate the word with anything (4), some linked it to the grey colour (2) or with bad weather (1).

The Polish word for edelweiss evokes associations with the grey colour while the German language nations link it with the white colour. The grey colour further embodies monotony or dreariness. It stands in contrast to the word colourful or colour, which both lead to further associations with pure 
colours. In Polish "edelweiss" is connected to something which is not worthy of our attention or something ordinary.

In the Polish version of the musical The Sound of Music from 2004, in the 82 nd minute of the film, there appears a translation in which the translator provides a literal translation of the song. The word edelweiss is translated into Polish without any additional explanations, which complies with the character of an audio-lingual translation. But this treatment of the original text makes the viewer confused: suddenly one can hear a song about an edelweiss, a flower which is not popular in Poland, and the song may be just treated as an ordinary song in the musical without any additional meaning. This is certainly an impoverishment of the message in the musical, which can hardly be avoided in an audio-visual translation, since in the Polish viewer's diegetic space, the extended meaning of the word edelweiss, which is present in German and American culture, does not exist.

When translating a text, we can make a Polish reader aware of additional associations with a given word by providing an explanation in a footnote, but we may fall into the trap of "over-translation" 7 if the additional associations given are too numerous. Hence, the translator needs to limit himself/herself to the situational context and the text. In some situations it may even be necessary, in order to fully understand Edelweiss, to provide the associations from language B (English). For example, when we as interpreters (tour guides) are giving a guided tour with The Sound of Music as a soundtrack, something which is offered to tourists visiting Austria. ${ }^{8}$

The translator's task is then to guess the meaning of a given symbol in a particular context in which the symbol acquires its meaning. This is obviously connected with the need for interpretation, and thus there is always the problem of whether the assumed interpretation corresponds not only to the translator himself but also to other people who are the receivers of the symbol in a given situation.

It can be concluded that interpretation is of a relative character. It may be viewed as an approximate, partial and relative attempt to understand symbols - which does not depend only on various factors but remains related to a number of possible readings of a symbol. The world of symbols is internally alive where some meanings disappear and something new is created instead. But the relationship between the disappearing symbol and the symbol that is created is dialectical.

\footnotetext{
7 According to Peter Newmark, over-translation is the result of cultural differences between various countries. (after: online: Mian Wang, <http://www.ier-institute.org/2070-1918/lnit17 /v17/129.pdf> (Date of access 23.05.2013).

8 The descriptions of the experiences of Americans (mainly tourists) after their participation in these guided tours can be found, for example in Rief 2009.
} 
The old meaning of the symbol by questioning its new meaning is often rooted in this new meaning, and thereby the continuity of its meaning is preserved. (Walczak 2011: 94)

Translation, then, is not about the ultimate interpretation of a symbol, which is impossible anyway, since the unification of its meaning will lead to the degradation of its expressive power (see Eliade 1993: 28; after Walczak 2011: 94):

The picture is true [...] as it is, as a set of meanings, not as one of its meanings or one of its many contexts. To translate an image into exact terminology and limiting it to one of its many contexts is worse than mutilating it, it is like destroying it, annihilating it as a tool of cognition.

In the light of the above considerations on the translation of the symbol, interlanguage translation can be viewed as a loss or a movement away from the meanings available in the culture of origin of these meanings. However, interlanguage translation can also be seen as a dialogue with this culture and a movement closer to it. This process will never end since the life of symbols is limited by time and the carriers of symbols may acquire new meanings in certain cultures.

In actual speech, except for a small group of defining sentences or utterances deprived of reflection, all other utterances are immersed in an exceptionally dense, individualized pool of intentions and understatements which silently modify and blur the shape of these utterances. Almost everything in human speech means something different than we think it does. (Steiner, 2000, s. 631). Steiner also pays attention to the untranslatability of texts from various historical periods or geographical areas. Since the language is constantly in flux and set in time, any reading of a text from the past is an act of interpretation. So, translations are not always possible and not always relevant to the original text. The contents of one language cannot be translated into another without losing some semantic fields. (Kawiorski 2014: http://psb.ur.edu.pl/sites/default/files/pdf/ uwagi_o_przekladzie_jezykowym.pdf > 4.11.2016).

The above considerations are very important from the point of view of the didactics of translating, interpreting and audiovisual translating. The example discussed here can help students to be sensitive to the complexity of translatory tasks, especially those which concern cultural phenomena of particular importance connected with the perception of a foreign culture, in our case with the problem of translating linguistic representations of hetero national stereotypes. The collective representations of the Other (Berting, Villain-Gandosai, 1995: 24) because of their nature, can constitute a problem for the translator. 
The translation of a symbol is conntected to the difficulties described in the translation literature in the context of intertextual references.

Intertextualität entsteht im Auge/Ohr der Rezipienten (d.h. sie kann auch unbeabsichtigt sein), wenn sie nicht erkannt wird, existiert sie nicht. (Nord 27)

Since until today no relatively unequivocal tools for the description of intertextual dialogue have been worked out (cf. Majkiewicz 2009: 123), from the perspective of theory as well as the didactics of translation, a wide freedom of interpretation of a given symbol is allowed. This relates to the difficulty of defining all possible and potential situations and means of connecting to pretexts (ibid) which in themselves are entangled in particular contexts and culturally rooted. The degree of openness of such connections is not always immediately visible by the translator of literary texts or a student studying a given culture as a foreign one. It would be tempting to list possible intertextual connections with respect to the obligatory and contextual canon (which is related for example with popular culture texts), which is postulated by e.g. Michał Głowiński (1986), Stanisław Balbus (1996), or Ryszard Nycz (1995) (cf. Majkiewicz 2009: 123). However, Majkiewicz suggests that in the context of intertextual entanglement of translation the obligatory or contextual canon should not be used. Rather, the importance of the semantic weight of a given term should be considered while the recognition of meanings indicated in a given work both implicitly and explicitly should be crucial (e.g. in the form of quotation with a change, in the form of allusion with the inversion figure, etc) (cf. Majkiewicz 2009: 124). This postulate is particularly important from the perspective of translation, and therefore also the didactics of translation. It frequently helps to avoid unintended associations in the reader of a target text which evoke ridiculousness (e.g. in reverse translation). On the other hand, the knowledge of a wide range of possible associations with a given term allows the translator to translate texts, such as adverts, more efficiently and with respect to a given target group, for example different age groups.

Showing the translation of a term on the basis of particular texts from different fields of translation (such as the above example of edelweiss in literary, film or advertisement interpretation) seems to be an interesting alternative for students who are usually offered classes where typically given texts - and contemporary meanings of given terms in context - are discussed. This could also include a possibly wide range of meanings, starting from the earliest to the ones occurring most contemporarily in a given culture (and of which the academic lecturer may not always himself/herself be 
aware $^{9}$ ) and defined by a preceding survey of the associations of students from both the original and target culture.

Discussing the problem with students allows us to start thinking in a divergent way, which is indispensable in finding proper ways of translating symbols which carry complex cultural meanings.

\section{REFERENCES}

Bednarczyk, A. 2005. Wybory translatorskie. Modyfikacje tekstu literackiego w przektadzie i kontekst asocjacyjny. Łask: Oficyna Wydawnicza Leksem.

Berting, J., Villain-Gandossi, Ch. 1995. The role and significance of national stereotypes in international relations: An interdisciplinary approach. In: Walas, T. (ed.), Stereotypes and Nations. Kraków: International Cultural Centre, 13-27.

Diem, P. 1995. Die Symbole Österreichs. Zeit und Geschichte in Zeichen. Mit 300 Schwarzweiß- und Farbabbildungen. Wien: A\&M.

Drügh, H. 2009. Overstanding Robert Wises The Sound of Music. Überlegungen zu Österreichs berühmtesten Film-Exilanten. In: Meurer, U., Oikonomou, M. (red.). Fremdbilder. Auswanderung und Exil im internationalen Kino, 87-106. (<http://www.transcript-verlag.de/ts1122 /ts1122_1.pdf>. Date of access 25.09.2013)

Eliade, M. 1993. Sacrum, mit, historia. Wybór esejów. Warszawa: Wydawnictwo Naukowe PWN. Głowiński, M. 1986. O intertekstualności. In: Pamiętnik Literacki, z. 4, 75-100.

Jung, C.G. 1976. Archetypy i symbole. Pisma wybrane. Warszawa: Wydawnictwo Czytelnik.

Kawiorski, S. 2014. Uwagi o przekładzie językowym. In: Podkarpackie Studia Biblioteczne, nr 3. <http://psb.ur.edu.pl/sites/default/files/pdf/uwagi_o_przekladzie_jezykowym.pdf> (Date of access 4.11.2016)

Majkiewicz, A. 2009. Intertekstualność jako nowe (stare) wyzwanie w teorii i praktyce przekładu literackiego. In: Rocznik Przekładoznawczy. Studia nad teoria, praktyka i dydaktyka przekładu. 5. <http://apcz.pl/czasopisma/index.php/RP/article/viewFile/RP.2009.009/903> (date of access: 8.03.2016).

Meyer, H.F. 2008. Blutiges Edelweiss. Die 1. Gebirgs-Division im Zeiten Weltkrieg. Berlin: Ch. Links-Verlag.

Newmark, P. 1982. Approaches to Translation. Oxford: Pergamon Press.

Nord, Ch. 2015. Ausbildung der Ausbilder: Was man für die Übersetzungslehre wissen muss. In: Badstübner-Kizik, C., Fiśer, Z., Hauck, R. (Hrsg.). Übersetzungsvermittlung. Translatorisches Handeln. Neue Strategien. Didaktische Innovation. Frankfurt am Main-Berlin-BernBruxelles-New York-Oxford-Wien: Peter Lang, 15-31.

Nycz, R., 1995. Tekstowy świat. Poststrukturalizm a wiedza a literaturze. Warszawa: Instytut Badań Literackich.

Rief, N. 2009. Sound Of Music: Der unbekannte Klang der Musik, <http://diepresse.com/ho me/panorama/oesterreich/467493/Sound-Of-Music_Der-unbekannte-Klang-der-Musik> (Date of access 5.09.2013).

${ }^{9}$ Mrs Joanna Ziemska, mentioned above, associated edelweiss with the protection of environment but not with beer. 
Scheidegger, T. 2008. Mythos Edelweiss: zur Kulturgeschichte eines alpinen Symbols. Eine Dokumentation, Recherchiert und verfasst im Auftrag der Botanischen Gärten, $<$ www.expo-edelweiss.ch> (Date of access 25.09.2013).

Steiner, G. 2000. Po wieży Babel: problemy języka i przekładu. Kraków: Universitas.

Strasser, Ch. 2000. «The Sound of Music» - Ein unbekannter Welterfolg: die virtuelle TrappEmigrantensaga als globale Kultur-Ikone mit Widersprüchen. In: Kammerhofer-Aggermann, U., Keul, A.G. (ed.). The Sound of Music: zwischen Mythos und Marketing. Salzburger Beiträge zur Volkskunde 11. Salzburg: Salzburger Institut für Volkskunde, 267-302.

Tillich, P. 1994. Pytanie o nieuwarunkowane. Pisma z filozofii religii. Kraków: Wydawnictwo Znak. Wang, M. 2013. An Analysis of Over-translation and Under-translation in Perspective of Cultural Connotation, <http://www.ier-institute.org/2070-1918/lnit17/v17/129.pdf> (Date of access 25.09.2013).

Walczak, A. 2011. O symbolu w kulturze i jego rozumieniu. Rozprawy filozoficzno-historyczne. In: Kultura i wychowanie, 1(1). <http:/ / www.pedagogika.eu/kiw_01/artykuly /KiW_1_87-101.pdf> (Date of access 25.09.2013). 